\title{
Establishment of an In Vitro LQT3 model Using Induced Pluripotent Stem Cells from LQT3 Patient-Derived Cardiomyocytes
}

\author{
Yoshiyuki Furutani, Emiko Hayama, Nanako Kawaguchi, \\ Yasuhiro Katsube, Eiko Oomichi, Mitsuyo Shimada, \\ Kei Inai, and Toshio Nakanishi
}

Cardiomyocytes derived from induced pluripotent stem cells (iPSC) are used to evaluate the function and risk factors of genetic variations linked to congenital and adult heart diseases in human beings. Our purpose in this study was to establish an in vitro cardiac disease model from an immortalized B-cell line stock using patientspecific iPSC-derived cardiomyocytes. Long QT syndrome (LQTS) 3 is caused by a gain-of-function mutation in the SCN5A gene, resulting in a prolonged QT interval as well as the development of early after-depolarizations (EADs). We generated LQT3-iPSC lines from immortalized B-cell lines transformed from peripheral blood obtained from a 24-day-old male (patient \#1) and an 11-year-old female (patient \#2), both diagnosed with type-3 LQTS due to SCN5A missense mutation (patient \#1: exon 28, G4868A, R1623Q; patient \#2: exon 20, G3578A, R1193Q). Several control iPSC lines were also created from samples collected from healthy candidates (26-36-year-old male and female). In both the generated patient iPSC lines, mutated genes were not altered after reprogramming, and normal karyotypes were observed. The pluripotency of all these iPSC lines was proven by in vivo teratoma formation and the expression of pluripotent stem cell marker genes and proteins. To evaluate the electrophysiological properties at the multicellular level, we studied the iPSC-derived cardiac cell layers with a microelectrode array mapping system (MED 64, Alpha MED Scientific Inc.). The recorded extracellular

\footnotetext{
Y. Furutani $(\bowtie) \cdot$ E. Hayama $\cdot$ N. Kawaguchi $\cdot$ E. Oomichi $\cdot$ M. Shimada $\cdot$ K. Inai

T. Nakanishi

Department of Pediatric Cardiology, Tokyo Women's Medical University, Tokyo, Japan

e-mail: yfurutani@twmu.ac.jp; nakanishi.toshio@twmu.ac.jp

Y. Katsube

Department of Pediatrics, Nippon Medical School, Tokyo, Japan
} 
electrograms were analyzed to measure the field-potential duration (FPD), which was normalized to account for variations in beating frequency, using Fridericia's correction (FPDcF, analogous to the QTc interval in the electrocardiogram). FPDcF was observed to be longer in LQT3 patient-derived specimens when compared to that in healthy control specimens (patient \#1: $P<0.05, N=17$ and patient \#2: $P<0.0001, N=19$ when compared to healthy control $N=39$ ). Moreover, EADs were observed in both LQT3 patient specimens after 15-30 nM of E-4031 was added exclusively to patient samples. The results indicated that LQT3 patient iPSCderived cardiac cells expressed prolonged QT duration (a common pathophysiological feature of LQTS) and EAD development with marked arrhythmogenicity in our in vitro disease model system.

\section{Further Reading}

Navarrete EG, Liang P, Lan F, Sanchez-Freire V, Simmons C, Gong T, Sharma A, Burridge PW, Patlolla B, Lee AS, Wu H, Beygui RE, Wu SM, Robbins RC, Bers DM, Wu JC. Screening drug-induced arrhythmia using human induced pluripotent stem cell-derived cardiomyocytes and low-impedance microelectrode arrays. Circulation. 2013;128:S3-13.

Open Access This chapter is licensed under the terms of the Creative Commons Attribution 4.0 International License (http://creativecommons.org/licenses/by/4.0/), which permits use, sharing, adaptation, distribution and reproduction in any medium or format, as long as you give appropriate credit to the original author(s) and the source, provide a link to the Creative Commons license and indicate if changes were made.

The images or other third party material in this chapter are included in the chapter's Creative Commons license, unless indicated otherwise in a credit line to the material. If material is not included in the chapter's Creative Commons license and your intended use is not permitted by statutory regulation or exceeds the permitted use, you will need to obtain permission directly from the copyright holder.

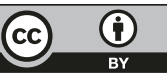

